\title{
Freedom and the Southern Economy
}

\author{
GAVIN WRIGHT
}

Department of Economics, University of Michigan

Writing in 1857, Hinton Helper predicted that "three-quarters of a century hence, if slavery is abolished within the next ten years, as it ought to be, the South will, we believe, be as much greater than the North, as the North is now greater than the South."' To a Northern observer of the 1970s generous enough to allow Mr. Helper the leeway of a half-century or so, his prognosis seems uncomfortably accurate. But in the nineteenth century, it was the poverty and disappointment of freedom which seemed most striking, the weakness and apparent perversity of the South's response to its own liberation. These are the central themes of One Kind of Freedom: the limited range of choices actually open to freedmen, the thwarted hopes for landownership, the stifling of progressive energies by exorbitant credit costs and racial barriers, the failure of the Southern economy to progress toward the national norm. As Helper's example attests, one could attempt to diminish the indictment by taking a longer view of the matter, by asking for a longer "time for adjustment" as it were, or by placing the South and the freedmen in a worldwide rather than merely a national comparative contest. Since historical conditions are seldom permanent, and since there are innumerable choices of comparative standards, this strategy can hardly fail; relativities like these are the historians' stock-in-trade.

In this essay I too propose to examine One Kind of Freedom in a broader context, not to celebrate the long-run outcome of the developments deplored by Ransom and Sutch, but to show the elements of ambiguity and relativity in the economic issues under debate. Historians thrive on relativity and altered perspective, but we economists tend to carry on our debates as though our terms and categories were firm and immutable. We need to be reminded that the past contains multiple realities; a simplifying abstraction which successfully captures the essence of some historical situation for some purpose should not be confused with the history itself. Many of the analytical distinctions and

1 Helper 1857, p. 142. 
working presuppositions. which economists have brought to the study of the postbellum South are not, in my view, well suited to unraveling important parts of that history. My purpose, however, is not to preach a new nihilism but to identify some points of implicit consensus and to propose an alternative organizing framework which yields operational suggestions for research.

\section{ECONOMISTS AND HISTORICAL THINKING}

Two aspects of economists' thinking that are relevant for my purposes are (1) the treatment of static allocational efficiency in product and factor markets as a norm, and (2) the neglect or the unhistorical treatment of risk and uncertainty. Nonhistorical economists might well express astonishment at these two items, since economics journals are filled these days with proposed models of market failure, models of behavior in the presence of risk and uncertainty, models of imperfect information and transactions costs, models of altruistic behavior, malicious behavior, political behavior, and random behavior, models of dynamic disequilibrium behavior, models of Marxian economic relations, and many more. Economics is not so narrow-minded as it is often depicted, but I believe these two phrases do aptly describe the economics that cliometricians have applied to history, and the explanation is not that cliometricians are poor economists. No one could possibly approach history or any empirical economic research with an infinity of theoretical possibilities in mind. Instead cliometricians do what all historians do, they come to history with a working conception of how an idealized economy works, which they commonly draw from the mainstream of conventional economics, and they examine the historical record either for confirmations or for deviations from that conception. In taking an efficient market resource allocation as a norm and then searching for deviations and exceptions, historical economists follow the format of economics teaching. Typically, students learn first the optimality properties of general competitive equilibrium in a world of profit-maximizing firms and utility-maximizing individuals; the instructor then moves through a conventional list of situations where these optimality rules are violated-external effects, monopoly power by firms or other organizations, consumer ignorance, racial discrimination, dynamic learning and technological developments, inequitable distributional results-and discusses the merits of government intervention in each case.

It is not necessarily true that this approach implies an antireform bias toward the status quo, nor a strong belief that markets do, by and large, work for the best. To prove this assertion with a counterexample, we need look no further than Ransom and Sutch, whose major research energies are devoted towards showing deviations from the competitive equilibrium: (1) in their treatment of slavery, they emphasize the exploitation 
which resulted from the fact that slaves were denied access to a free labor market; (2) their interpretations of debt peonage revolves crucially around the argument that merchants established territorial monopoly power in credit markets; (3) they define "overproduction" in terms of the relationship between the ratio of cotton and corn prices on the one hand, and the marginal rate-of-transformation in production on the other; (4) they fault sharecropping because it allowed land-labor ratios to differ inefficiently on farms of different tenure types; (5) and they view racial discrimination as resulting in large part from faulty beliefs by whites in innate racial inferiority. This list does not do justice to the many subtleties and insights in the connecting narrative, but these are the hypotheses which are formally developed and stressed. The purpose of the list is not to launch a refutation of these propositions, but to argue that Ransom and Sutch's definition of the important issues has largely been shaped by the focus on competitive equilibrium as a norm. And in common with many other economists, they tend to presume that the important factors in determining the rate of economic progress for blacks and for the South are closely related to the allocational efficiency of the Southern economy.

The organization of discussion around deviations from a competitive norm may be useful in many respects, but it is only one of many possible organizing principles, and it is highly abstract and simplified. Despite appearances, most of the issues which derive from this framework are not objective and well defined, because of the existence of risk and uncertainty in the real world. For example, "overproduction" in the Ransom-Sutch sense cannot be conclusively tested because cotton and corn yields were variable and uncertain, and the interaction between cotton and corn yields in a context of uncertainty is a complex, probabilistic phenomenon. Similarly, monopoly power is not sharply definable in a context of risky loans for risky purposes, spatial competition, and price discrimination. The spatial theorist Melvin Greenhut writes that "the inclusion of economic space requires recognition and acceptance of uncertainty as a basic property of the system. We also . . . find that economic space, uncertainty, and oligopoly go hand-in-hand. " ${ }^{2}$ My point in making these observations is not to say that the Ransom-Sutch categories are meaningless or useless, but only to argue that we need to ask not so much whether these analyses are precisely true, but how well these abstractions really capture the most essential elements of the historical situation. On some of these points, it appears that the attempt to translate contemporary comments into this economic framework has led them into some conceptions which are narrower and weaker than they need to be.

Now cliometricians frequently do have to confront the reality of risk

${ }^{2}$ Greenhut 1970, p. 4. 
and uncertainty in the world, and when they do, they draw on a large economic literature. But the concept of uncertainty as it is used by nonhistorical economists is nonhistorical; by and large, uncertainty is treated as riskiness, which is an intrinsic attribute of an asset or an activity, and when cliometricians appropriate these theories, they merely broaden the notion of equilibrium to include premiums for riskiness. This approach to risk is a common dimension of the otherwise quite different analyses of sharecropping advanced by Robert Higgs and Joseph D. Reid, $\mathrm{Jr}^{3}$. Changes in these institutions over time are taken to be moving equilibria, responses to changes in riskiness or in the degree of riskaversion in the population. In this way uncertainty is reduced to certainty equivalence, without any essential effect on the character of the analysis. This approach is useful in analyzing sophisticated financial markets, but it does violence to history and historical modes of thought. The record of Southern history from the Civil War until World War I is not fifty years of "riskiness" but is simply a recording of fifty outcomes of activities carried out in a context of uncertainty. As historians we ought to entertain and indeed make the most of the notion that many of these outcomes were unlikely; and since in the historical mode of thought, these games of chance were not independent but serially connected, much of the whole history may have been improbable in some reasonable sense of that term. ${ }^{4}$ From this vantage point, there is an essential indeterminacy to the debate over whether the merchant's credit charges were "justified" by risk, since we have only ex post measures of default and variance to go by. This is only one example of the widely demonstrated proposition that it is difficult and often impossible to infer behavioral or utility functions from observed market outcomes. ${ }^{5}$

Let me propose a methodological strategy which might help us to escape the present impasse. First, in the hopes of focusing on objective and operational rather than subjective and unresolvable issues, I suggest that we reduce our attention to questions of motivation and tests of optimizing behavior, and concentrate instead on identifying the relevant constraints on choices, the set of options actually open at any time to tenants, landlords, merchants (and the economy as a whole), and how these changed over time. Second, I suggest that we focus on a magnitude which is objective, which constrains choice, and whose determination reflects a cumulative historical process, namely wealth. Third, I suggest that we not look for the "representative" tenancy or the typical credit market structure (monopoly or competition), but that we analyze explicitly the distribution of the relevant population in both the spatial and statistical

${ }^{3}$ See Reid, 1973, 1976; Higgs, 1973, 1977, pp. 50, 67-68.

4 For an analogous argument, see Crafts, 1977.

${ }^{5}$ See Sanderson, 1974; Sonnenschein, 1973. 
senses of that term. The following sections explore some of the disputed issues with these precepts in view.

\section{LABOR SUPPLY, LAND, AND WEALTH}

A major contribution of One Kind of Freedom is the finding that most of the decline in output after the war is attributable to the reduction in effective labor supply from the black population, a reduction which they estimate to be between 28 and $37 \%$ per capita. Whether the labor-supply effect accounts for the whole of the fall in per capita output between 1860 and $\mathbf{1 8 8 0}$ (or whether there is significant room for an additional loss of plantation scale economies) remains a bone of contention; but there seems to be a consensus on the reality and significance of this voluntary withdrawal of labor from the fields. In their text, Ransom and Sutch demonstrate that mules were in ample supply after the war (p. 49); they minimize the burden of replacing the farm capital physically destroyed by the war (p. 50), and they give particularly short shrift to cultivable land as a factor of production on the grounds that "the war did not, of course, literally destroy the land. Therefore, with the decline in the labor supply it is obvious that the land-labor ratio must have risen" (p. 48). They note that the "improved acreage" reported in the 1870 census was actually $20 \%$ below the level of 1860 , suggesting that "only limited scope existed for increasing the land-labor ratio" (p. 48).

This all seems clear. But there is a surprise waiting if we actually compute the ratio of acreage to effective workers on the slave plantations of 1860 and black family farms of 1880 . Using the information on p. 184 of One Kind of Freedom, we find that the black family farms of 1880 averaged 7.5 acres of crops per worker, or 3.0 acres per family member. Applying relatively generous adjustments for improved acreage other than cropland, these figures translate into roughly 9.4 and 3.7 improved acres, respectively. In the Parker-Gallman sample, plantations with more than 50 slaves averaged 8.4 improved acres per capita, or more than 9 improved acres for each member of the black population. In other words, far from attempting to increase the land-labor ratio with emancipation, planters actually reduced the per capita allotment of improved acreage by about $60 \%$, a reduction roughly twice the size of the per capita withdrawal of black labor. One may quarrel over precise measures and over the representativeness of these two classes, but the conclusion that the labor intensity of cotton cultivation actually increased is difficult to escape in the aggregate. In the five-state area, the ratio of rural population to improved acreage was more than $40 \%$ greater in 1880 than it had been in 1860 , a good bit more than the black labor-supply effect can account for. Ransom and Sutch have overlooked this development because their references to land are to the aggregate stock, whereas their analysis of labor supply is in per capita terms. 
These considerations do not, of course, falsify the Ransom-Sutch contention that the withdrawal of black labor was the dominant development of the postwar economy, but they lead me to wonder whether they have told the full story. Their estimates (pp. 232-236) are heavily weighted by observation in the late 1860 s and early 1870s. Their description of a persistent "labor shortage" rings true for that period, and it is difficult to see how else to account for the useable acreage standing idle in 1870 "for the want of labor." But by 1880 improved acreage had returned to its 1860 level, and it is not evident that good cotton land was in surplus. There is reason to believe that labor markets were much softer in the late 1870 s than they had been a decade before. This was partly a political development, as the federal government abandoned their efforts to police Southern labor relations, and freedmen reluctantly abandoned aspirations to independent farmownership. But the changed climate also reflected underlying trends in the Southern economy, particularly the continuing pressure of population and the steady deterioration of the cotton price between 1866 and 1879. The accelerated growth of the Southern textiles industry, which required an ample supply of cheap labor (but which employed few blacks) dates not from the 1860 s but from the late $1870 \mathrm{~s}^{6}{ }^{6}$ The small black family farms of 1880 were cultivated so intensively (Ransom and Sutch, pp. 183-185) that one has to wonder whether the families could profitably have clocked more hours if they had wanted to.

The welfare interpretation of the hours of labor is thus fraught with ambiguities. It seems utterly reasonable that free black families would want to work less than slaves, but it is worth remembering the modern studies which indicate that the self-employed work much longer hours

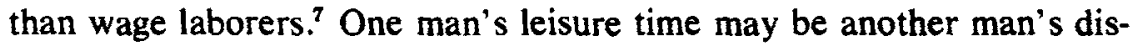
guised unemployment, and what began as a new liberation may have been transformed over time into a new constraint. Gallman and Anderson have argued plausibly that "changes in the work proclivities of freedmen may not have been altogether a product of their choice . . . [because] labor no longer had the character of fixed capital to the planter." ${ }^{8}$ They propose that the revolution in property rights changed the effective principles of resource allocation, and their argument directs our attention to the impact of wealth on the behavior of planters. The search for a summary measure of efficiency may have caused us to overiook a more fundamental development, but we would never see it if we insist upon a "long-run" framework where detached producers respond only to the relative prices of factors of production.

${ }^{6}$ The timing of the acceleration is documented in Griffin, 1964, pp. 48-49. Testimony on the labor-supply effects of the falling cotton price may be found in Griffin, p. 46; Smith, 1960, p. 6; Mitchell, 1921, p. 145.

${ }^{7}$ Scitovsky, 1976, pp. 94-95.

- Gallman and Anderson, 1977, p. 41. 
Wealth is also critical in the labor-supply behavior of workers, as we may learn from a recent theoretical analysis of slavery by Yoram Barzel. ${ }^{9}$ Barzel develops a model similar to Fogel and Engerman's, in which the profit-maximizing behavior of slave owners compels the slave to work longer and with greater intensity than an unconstrained freeman, producing more output and (because of the harder work) consuming more food. In a brief but significant section, Barzel goes on to show that exactly the same combination of work and output would be produced by a constrained freeman who is burdened by the need to repay a debt which is just equal to the net exploitation of a slave. Barzel observes that the comparison of free and slave equilibrium points "can be viewed as continuous and dependent on the level of wealth" (p. 91). My own view is that the higher apparent productivity of slave labor had more to do with specialization in market production than with the intensity of labor time. But the general message-that the constraints of debt can produce a self-coercion analogous to the outright coercion of slavery-ought to give us pause. No one would argue that the work patterns of slavery were restored, but liberally interpreted along crop-mix lines, Barzel's model fits the facts: When free farmers were impelled by indebtedness to move into production for the market, the cotton price settled at the same level as in the days of slavery.

\section{FARM TENANCY AND CROP MIX}

This brings us to the question of why the resources of Southern agriculture in $\mathbf{1 8 8 0}$ were so much more fully devoted to cotton than they had been in 1860 . The real issue is explaining the dramatic decline of selfsufficiency in basic foodstuffs. The recent literature contains many hypotheses about the motives and behavior of farmers, landlords, and merchants in this connection. Ransom and Sutch point to the insistence by lenders that borrowing farmers plant a certain quantity of cotton as a precondition for credit; the behavior of the merchant is said to involve not merely a demand for collateral, but an effort to "drive the farmer into increased dependence upon purchased supplies" (p. 161); these requirements are said to have locked in debtor-farmers to overproduction of cotton (pp. 165-168). ${ }^{10}$ Critics of this analysis have denied that merchants possessed monopoly power in credit markets, disputed the claim that merchants controlled planting decisions (or would have done so in a detrimental manner), and have doubted whether cotton was "overproduced" in any reasonable sense. ${ }^{11}$

There are obviously many different opinions here, but there is an

- Barzel, 1977.

${ }^{10}$ A more detailed elaboration may be found in Ransom and Sutch, 1975.

11 Besides the papers of Goldin and Temin, see DeCanio, 1974, pp. 111-118, 241-261; Higgs, 1977, pp. 57-59, 71. 


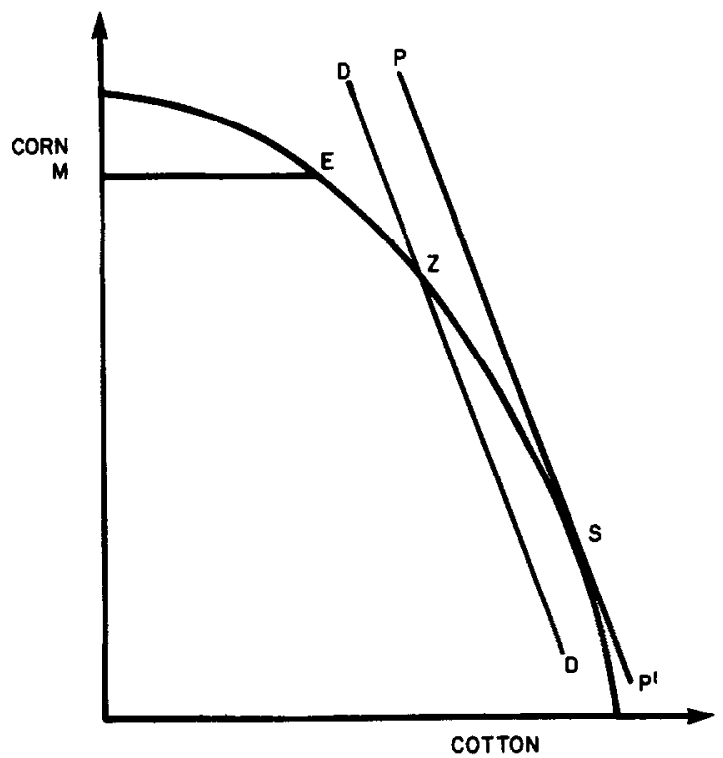

FIG. 1. The choice between cotton and corn.

essential core explanation to the main historical change which need not be controversial if we focus on objective constraints rather than motives. That is the proposition that self-sufficiency is not possible on very small tenant farms, where the tenant has borrowed substantially to get through the crop year. Refer to Fig. 1, adapted from Ransom and Sutch (1975), which illustrates the production possibility choices between cotton and corn: line $M E$ denotes the corn requirements of the farm; at point $S$ expected profits are maximized; and line $D D$ (the slope of which reflects the relative prices of cotton and corn) represents the level of indebtedness.

In 1860 small farms were self-sufficient at a point like $E$, despite the fact that this choice did not maximize profits ${ }^{12}$ we may not agree on precisely why they chose this point (whether it was risk, leisure preference, ignorance, or something else), but whatever their reasons, it is evident that that choice was no longer open to a small farmer with indebtedness $D D$. If one prefers to stress the labor-leisure trade-off, one could draw the analogous diagram (following Barzel) with much the same implications. As Temin notes, it is difficult to say but not really important whether the tenant himself takes the initiative in expanding his cotton acreage in order to pay back his loan, or whether (as it might appear to the tenant) the merchant's insistence is the essential element. But Temin's phrasing illustrates the importance of focusing on constraints:

12 An extended review of the antebellum self-sufficiency literature which appeared in an earlier draft has been omitted here to conserve space. A helpful survey may be found in Gallman and Anderson, 1977, pp. 32-39. 
The cost of borrowing, was a sunk cost at the time of planting. Irrespective of what he planted he would have to pay interest to the merchant to get through the year. But this interest should not have been a factor in his decision of what to plant. (Emphasis added.)

The first point is valid and important-that the need to borrow is prior to and independent of the subsequent planting. The second is the economists' familiar slogan: Bygones are bygones, and sunk costs do not matter. But that is only true if farmers intend to maximize profits at all times: If they had intended to do something substantially different, as they typically did in 1860 , then the bygones of history did matter, because their legacy (the debt) ruled out options, which, for one reason or another, many farms had chosen in the less constrained situation of 1860 . Furthermore, we need not agree on the theoretical reasons for the high interest rates by merchants, in order to see that the higher the interest charges, the heavier the burden of the debt will be, and the further the tenant will be pushed into cotton. One need only glance at the differences in cottonintensity on owned and rented farms (Ransom and Sutch, p. 157) to see how clear the association is between the rise of cash obligations and the shift into cotton.

Some writers have characterized the difference between Ransom and Sutch and their critics as a debate over whether "the market works" or not. But this is an ambiguous criterion: One can reasonably argue that Fig. 1 describes the way in which markets $d o$ work, not by magically equilibrating marginal trade-offs at every instant, but by pushing producers towards an efficient crop mix (albeit, with the possible sacrifice of some nonpecuniary goals). As the discussion at the Duke conference made clear, there is no technical issue of substance over the notion of "overproduction": No economist now defends the view that merchants forced production of cotton to the right of point $S$ in Fig. 1, at least in normal years. The remaining differences revolve around more subjective considerations: Can we understand contemporary use of that term sympathetically, so as to enhance our understanding rather than demonstrate our more rigorous terminology? "Overproduction" is a knee-jerkreaction word for economists: They hear it and they think "fallacy." When they read contemporaries bemoaning food imports as a drain on regional wealth, economists are sure they are dealing with utter economic ignorance. But economists should not react so quickly: If the elasticity of demand were unity, as it seems to have been for at least a substantial range, the belief that food imports were a net drain on the South was precisely correct. The South could have obtained the same cotton earnings producing less, and the homegrown food would be strictly gravy. There was thus a resonance between the optimal regional allocation and the traditional means of maintaining small-farm independence, which should help us to appreciate the continuing temptation of intellectuals to 
draw colorful parallels between the micro and macro developments. It didn't take an intellectual cotton farmer, however, to appreciate the fact that at the micro level, the loss of self-sufficiency involved a basic change in the character of social relations. With or without monopoly power, the debt was held by someone, and that creditor was bound to show a keen interest in the farmer's reliability, diligence, crop choice, spending habits, and so on; the farmer in the clear and self-sufficient at point $E$, in contrast, didn't have to take manure from anyone.

But Ransom and Sutch clearly describe a more involved calculation, in which the merchant did not merely try to ensure repayment of his exorbitant loans, but attempted to determine the wealth position of the farmer at the end of the year, so as to ensure his patronage in the following season. This is a difficult calculus to document, but it appears from their text (pp. 162-165) that Ransom and Sutch believe such a mechanism is needed to explain the persistence of indebted situations like Fig. 1. If self-sufficiency were attractive and credit expensive, why shouldn't small farmers have escaped from their dependent positions at the first opportunity? However, a reasonable simulation exercise might show that it just wasn't that easy to climb out of an initial indebted position with the earnings of a small family farm. For a family which begins without wealth, given the acreage on a typical tenancy, given plausible estimates of subsistence requirements and interest rates, is it in fact true that any crop mix between points $Z$ and $S$ would have allowed the accumulation of enough net worth to make possible a return to self-sufficiency-given the actual course of prices and yields over a particular span of time? This is, at any rate, an operational approach which might serve to reduce the bounds of disagreement. A farmer might say that he is trying to "escape the clutches of the merchant" in much the same sense that we all try to escape the clutches of the dentist or the undertaker - not so much because he is a monopolist but because he is providing a service we would rather not consume. The likelihood that the observed patterns of farm wealth, with the persistence of indebtedness and specialization in cotton, can be generated by the impersonal historical record in this way, is enhanced by the realization that the small-farm, low-wealth categories were constantly being replenished by the pressure of population. Ransom and Sutch's figures show (Table 8.3, p. 159) that a substantial majority of farms of medium scale or larger did in fact achieve self-sufficiency in foods.

\section{THE DETERMINATION OF FARM SIZE}

Ransom and Sutch consider the analysis of the previous section incomplete. Figure 1 may characterize the position of an indebted landowner with a small holding, or a share tenant after his contract has specified the plot size; but to the landlord (and perhaps ex ante to the tenant), the size of the plot was open to determination. In their view, establishing the 
amount of land to be leased served as a supplement to supervision as an instrument of labor control, ensuring labor intensity in cultivation. Since "labor intensity" can be translated into "cotton intensity" with little loss of accuracy, we can view the crop mix as determined (implicitly or explicity) in the bargain over the plot size (pp. 97-99, 348).

The impulse to move towards labor intensity in comparison with antebellum practices is clearly explained by Gallman and Anderson. A slaveowner with limited or costly access to a rental market will try to fill in the work year as fully as possible; with his net investment dominated by the value of the slaves, he will try (approximately) to maximize the value of output per worker, assigning each hand as much acreage as possible. But when his property consists of the land alone, and labor is hired by the day or the month, the employer will cut out all labor activities which don't "pay for themselves" at the going wage. Alternatively, we can view him as now attempting to maximize the value of output per acre; since there is no disputing the superiority of cotton over food crops in terms of their yield per acre, this meant a shift toward cotton. As the GallmanAnderson analysis would predict, emancipation transformed the planters' attitude toward regional inflows of labor. ${ }^{13}$ And while economists frequently point to the spread of railroads and marketing channels and the rise of commercial fertilizer as alternative explanations for the shift into cotton, we can (with a certain license for hyperbole) view the favorable atmosphere for all of these developments as a manifestation of the planter's newly developed desire to augment the value of his land and maximize the value of output per acre..$^{14}$

Returning to the micro level, the question becomes whether renting and sharecropping produce the same allocation pattern that landlords would have desired in dealing with wage labor. The answer seems to be that many landlords were able to use tenancies of both kinds to much the same effect by keeping plots small, encouraging and enforcing labor and cotton-intensity. As Joan Robinson and John Eatwell argue, describing a hypothetical sharecropping economy, "the landlord gains most when the holdings are small and the level of intensity of cultivation so high as to maximize output per acre. . . . From the landlord's point of view, the smaller the holding per tenant the better, provided that it is not so small that the tenant families are unable to live. "15

Now the success of the planter in this endeavor is only possible if labor

${ }^{13}$ See Berthoff. 1951: "Plantation owners led the movement to bring in foreigners" (p. 328).

14 The "penetration" of the South by railroads and Northern merchants is described, in somewhat conspiratorial terms, by Woolfolk (1958). On the spread of cotton processing facilities and Southern urbanization, see Weiher, 1977. On the fertilizer industry, see Taylor. 1953.

${ }^{15}$ Robinson and Eatwell. 1973, p. 70. 
can be put in such a position, and it is in this connection that we will see the matter most clearly if we focus directly on the distribution of the tenant population in terms of geographic and economic alternatives (i.e., the elasticities of their labor supply to an individual landlord), rather than trying to reach a summary characterization of the market as "competitive" or "coercive." A distinctive feature of spatial competition is that even firms which are competitive in the usual sense will nonetheless attempt to practice discrimination among their buyers. ${ }^{16}$ My corner druggist may have some spatial market power, but if he cannot distinguish one customer from another, I will capture the full benefits of competition on the "fringe" even if I live next door. As soon as the druggist begins to give credit, however, the situation changes: The lender's concern for the identity of the borrower will have to carry over beyond the immediate transaction. His desire for information and assurances is only reasonable, but in the process of this negotiation, he is also acquiring the means of discrimination. The fact that the druggist may be economically marginal will not give his intramarginal customers much protection.

Ransom and Sutch have emphasized the merchant because it is easier to build a case for monopoly pricing there, but when one remembers that economic discrimination is an intimate aspect of spatial competition, these considerations apply with equal force to the landlord. Even a landlord who does not supply the "furnish" is engaged in a kind of "credit" transaction, in that he is renting out durable assets and is concerned for their treatment. Thus there is a difference between a wage system and tenancy: And that is that when we move from a situation in which one impersonal wage is obtainable to all comers to a world of heterogeneous one-on-one bargains with detailed specifications (as Reid emphasizes), discrimination in the economic sense is not only possible but inevitable. ${ }^{17}$ And in a racist society, this economic discrimination will be highly correlated with race. The protections of the market are much weaker when economic discrimination is possible, because those who can be exploited probably will be, even while the more mobile tenants were able to drive hard bargains. The wide differences observed in land-labor ratios and in the fortunes of tenants are prima facie evi-

\footnotetext{
${ }^{16}$ See Greenhut and Ohta, 1975: "A major difference-indeed the major differencebetween spaceless and spatial price theory lies . . . in the premise that in classical economic theory competitors were conceived only to price nondiscriminatorily, while spatial competitors ... generally discriminate in price“ (p. xiii).

${ }^{17}$ It is not surprising that Higgs (1972) finds little discrimination in farm-labor wages, but the scope of this result may be narrow. Ransom and Sutch (footnote 63, p. 339) assert that share arrangements are different in these respects from fixed renting contracts, in which "the rent per acre is the subject of negotiation, but once set the renter may in principle take on as many acres as he wishes." But because of the heterogeneity and vulnerability of land, I believe we will find that fixed rent agreements also specified a particular acreage as well as a rental fee. If so, then the element of discrimination is present here too.
} 
dence that landlords were able to take advantage of limited geographic mobility on the part of tenants. ${ }^{18}$

Ransom and Sutch are quite right to insist that plot sizes are not demographically determined, but were objects of bargaining and strategy; but it is also true that the same trends were encouraged by the essentially demographic fact of the rise in rural population relative to improved acreage. On this count, it may be that the war itself was more costly than Ransom and Sutch allow, because the absolute level of improved acreage had barely reached its 1860 level by 1880 in the five-state area. In places, Ransom and Sutch seem to argue that landlords were actively holding back usable land (pp. 348, 351). Robinson and Eatwell, in the passage previously cited, also contemplate such a situation when they write:

\begin{abstract}
When there are not enough tenants to cultivate the whole area, the landlords will not let out such large holdings that output per acre falls very low; they prefer to keep a part of the land unlet . . . to prevent the peasants from becoming prosperous and independent.
\end{abstract}

Perhaps this is the Ransom-Sutch position, and perhaps it does describe 1870. But from the 1870 s onward, it is difficult to understand an economic rationale for holding the major income-earning asset out of production as a regular matter. One suspects we need better evidence and a better argument to buttress the claim that land was macroeconomically in surplus in 1880 .

\title{
THE CHOICE OF TENURE
}

Ransom and Sutch discuss the displacement of wage systems by sharecropping in detail (pp. 87-103), but as Engerman observed, they do not devote much attention to explaining temporal fluctuations and regional variations in tenure form; in general, our understanding of the coexistence of share and fixed-rent tenancies is limited. Robert Higgs views sharecropping as a risk-sharing arrangement, as contrasted with wage labor (where the planter bears the risk) and fixed-rent tenancy (where the tenant bears the risk). Higgs explains coexistence in terms of individual and local differences in risk aversion and the riskiness of crops; and changes over time (e.g., the rise of sharecropping after 1900) by changes in the riskiness of agriculture (caused by, e.g., the boll weevil). ${ }^{18}$ Reid, on the other hand, denies that sharecropping served this kind of risk-sharing function, on the grounds that landlords and laborers could obtain equivalent risk-return combinations by mixing portfolios of fixed-wage and fixed-rent bargains. He develops an alternative model, in which sharecropping has many efficiency advantages when tenants are young or inexperienced, because of the mutual incentives to share advice,

18 A geographic interpretation of racial differences appears in DeCanio, 1974, Chap. 6.

${ }^{19}$ Higgs, 1973, Higgs, 1977, pp. 67-68. 
assistance, supervision, etc., throughout the crop year. ${ }^{20}$ Ransom and Sutch, in rebuttal, note that the life-cycle farm-ladder hypothesis fits the data much better for whites than for blacks (p. 181), an observation which would be consistent with Reid's analysis in conjunction with the Ransom-Sutch market signaling effect.

We can't settle all these issues here, but the principle of Occam's razor suggests a simpler explanation, which emerges when one reflects on the fact that the wealthlessness of farm tenants imposes a constraint on the ability of landlords to avoid risk by fixing rents. No one can squeeze blood from a stone, and if the crop fails or the price of cotton falls out, the legal claim to a fixed rent is small consolation if the tenant is penniless. The constraints of wealth do not rigidly determine a set of tenure arrangements, but they clearly established bounds on the number of tenants who occupy the upper rungs of the ladder: farm ownership and fixed-rent tenancy. A wealthy man might choose to work on shares (and those who supplied mule and tools could and did work under the "thirds and fourths" system); but a poor man could not become a fixed-rent tenant until he raised the funds for his own mule and equipment. There are indications that this was the binding constraint in many cases: Nate Shaw tells of how he scraped together $\$ 100$ for his own mule, borrowing the last $\$ 20$ from his father-in-law, and he says: "Got me a mule and gived up working on halves. . . . Paid cash rent and made a profit from my farmin." 21

Hibbard's 1913 survey of Southern Tenancy describes "a well-defined caste system among the tenants". $:^{22}$

The lowest class is represented by those who furnish little equipment and receive half, or less, of the crop; above this comes the group whose independence is measured by the possession of a mule and a plow and the means of subsistence till harvest time; the highest class consists of those who can be trusted to deliver a certain quantity of crop or possibly a sum of money, and who are by that fact emancipated in the main from the directing authority of the landlord.

Hibbard's criteria clearly encompass Reid's subjective elements, but they also indicate that asset-ownership and wealth were preconditions or entry-barriers into the renting class. Thus, the hypothesis suggests itself that the coexistence of tenure types and their relative change over time primarily reflect the success of farmers over time in accumulating and retaining assets, an accumulation which was constrained at any time by wealth.

It is difficult to test this hypothesis, because the last census to collect

20 Reid, 1973, 1976.

${ }^{21}$ Rosengarten, 1975, pp. 117-118.

${ }^{22}$ Hibbard, 1913, p. 486. For other statements relating the move into renting to asset accumulation, see Brooks, 1912, pp. 60-65; Edwards, 1913, pp. 24-26. Compare Bell and Zusman, 1976, pp. 579-581. 
household wealth data was 1870 , and the first census to enquire into farm tenure was 1880 . But I have carried out a limited test for Georgia in 1900 , using county data on hlack wealth, collected by W. E. B. DuBois from tax records ${ }^{23}$ This evidence indicates that the fraction of black farm tenants who are sharecroppers is negatively related to the average value of workstock and tools owned by blacks (or other measures of wealth), and with the fraction of black farmers in a county. The regression is

$$
\frac{\mathrm{SHR}}{\mathrm{TEN}}=\underset{(2.85)}{1.30-8.45^{*}} \frac{\mathrm{WLTH}}{\mathrm{TEN}} \underset{(5.3)}{-0.010^{*} \% \mathrm{BL},} \quad R^{2}=0.564
$$

where $t$ ratios are in parenthesis. (The sample is 33 counties in the Georgia cotton belt for which data are available.)

Wealth is, of course, correlated with age and experience, and this argument is not advanced as a wholesale substitute for Reid's analysis. But the county data show much wider variations in levels of wealth than one would expect to see in age-experience structures, and the wealth hypothesis can readily account for the sharp differences in the age-tenure relationship for blacks and for whites. Finally, the analysis helps in understanding why the relative importance of sharecropping should have risen sharply after 1900 for both blacks and whites, at a time when the cotton economy was generally prosperous, and the percentage of black landowners was rising. It seems paradoxical, but there is a straightforward reason: namely, that the price of mules doubled between 1899 and 1905, and tripled between 1899 and 1918. Figure 2 depicts the dramatic developments. The same price pattern holds for mules of all ages and, because mules are transportable, for all parts of the South. The price of a mule was the main barrier between share and fixed-rent tenancy, and it appears that this barrier was rising faster than earnings, even while the landownership barrier was becoming a little more surmountable. One would expect the trends to diverge for the two assets, because land can be purchased in small and inferior lots, whereas mules are less divisible. ${ }^{24}$

The rising barriers to the acquisition of mules, tools, and fixed-rent tenure had important social consequences as well, because there is reason to believe that the sharecroppers of 1910 had less of the day-to-day independence and decision-making scope described by Ransom and Sutch for the $1880 \mathrm{~s}$ (pp. 94-99). The continuity in the names of census

\footnotetext{
${ }^{23}$ DuBois, 1901.

${ }^{24}$ It is difficult to determine from the available literature the precise reasons for the fluctuations in mule prices. Since three-fifths of U.S. mules were used in the South, one would expect that the cotton boom itself is part of the story. But mules were raised outside of the cotton areas, and the parallel trend in the price of horses (less than one-quarter of which were used in the South) suggest that supply-side pressures or competing demands must also have been involved. Lamb (1963) is less informative than one would like.
} 


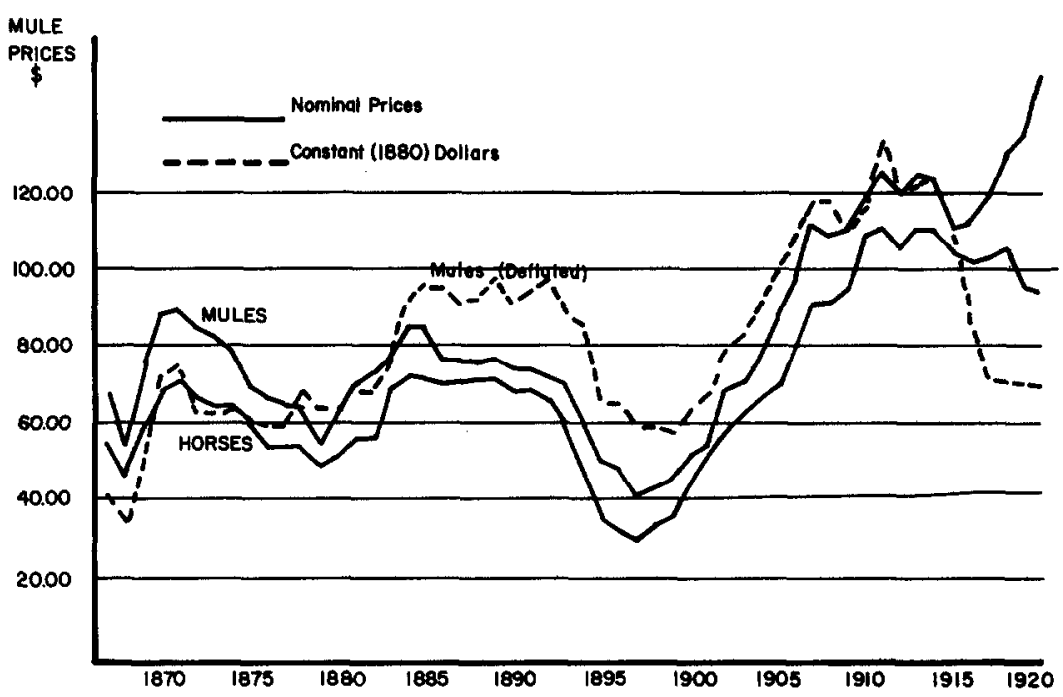

FIG. 2. Average prices, U.S. mules and horses, 1866-1920. Source: Historical Statistics of the U.S. (1976), Vol. I, pp. 200-201, 519-520.

categories may in this respect be quite misleading. R. P. Brooks, writing in 1913, insisted that a sharecropper was little more than a share-wage day-laborer, and criticized earlier writers (notably Banks and Hammond) for treating sharecropping as a tenancy. ${ }^{25}$ Brooks, like many subsequent historians, may not have appreciated the changing and evolving character of Southern economic and racial relationships. We cannot be sure, because we lack detailed knowledge of the degree of centralization of production decisions in either the earlier or later period, and we cannot safely rule out the possibility that black and white sharecropping were two quite different things with the same name. But if Ransom and Sutch are essentially correct in their account of the "one kind of freedom" which the former slaves had achieved by 1880 , then the post- 1900 reports suggest that even this limited household freedom had been badly eroded, under legal, social and racial pressures, by the time of World War I. Harold Woodman, in a useful discussion of these trends, suggests that the entire period be viewed in terms of "the making of a working class" of wage laborers, by analogy to the evolution of class relationships in industrial capitalism. ${ }^{26}$ Applying Occam's razor once again, however, I suggest that the more immediate reason for these developments was the renewed acceleration in world cotton demand after 1900 . If this is right, then we have another example of the pattern which began with slavery, an inverse

\footnotetext{
${ }^{25}$ Brooks, 1914, esp. pp. 66-68. Compare Banks, 1905; Hammond, 1897.

${ }^{20}$ Woodman, 1977, pp. 551-554.
} 
relationship between the demand for labor and the legal and social status of laborers without property.

\section{THE LIMITS TO PROGRESS}

The most important constraints to identify are the feasible limits to Southern economic progress in the 19th century. This is not the main focus of One Kind of Freedom, and their concluding chapter is largely a listing of various growth inhibiting effects with which, in qualitative terms, it is difficult to disagree. But the overall emphasis of the book, coupled with the statement that "the core of the problem of underdevelopment is institutional," carries with it the implication that the performance of the agriculture sector could have made a significant difference in regional progress, and it is worth noting that there is room for doubt on this score. Did the region possess "all the requisite conditions for rapid economic growth" (p.7)?

The hard economic facts of the Southern economy were that black and white fertility rates were far above the national average, and that between the Civil War and the turn of the century the natural growth of the rural population averaged nearly $2 \%$ per year-about as fast as the growth of world cotton demand during this period, and substantially faster than the growth of land on farms. Outmigration from agriculture made very little dent in these rates. Rubin (1975) makes a strong case that geography seriously constrained Southern efforts at diversification, and the unfortunate truth is that the harshest critics of cotton were unable to suggest an alternative source of cash income for farmers. A broadening of landownership and self-sufficiency in food crops would have been equitable and humane, and might even have raised cotton prices; but there is not much reason to believe that such a program would have generated sustained progress. As Engerman has stressed, the examples of emancipations where the freedmen had access to land do not encourage optimism that the dictates of equity and progress will necessarily coincide. We can all agree that Southern agriculture could have been more progressive; but rapid productivity growth in the cotton sector would have been of little help to rural incomes if labor had no outlet. One of the reasons (among many) for the slow development of the mechanical cotton picker was the inventors' belief that the machine would inflict misery on the Southern poor. ${ }^{27}$

To understand Southern poverty, therefore, we will have to look into the determinants of population growth, the obstacles to Southern industrialization and the course of migration to Northern jobs. It may well be that the institutions of Southern agriculture have a role to play on each of

${ }^{27}$ Street, 1957, pp. 62-64. 
these points, and such a study will be able to build on the research of Ransom and Sutch. But the connections remain to be developed precisely, and the full story will have to include American immigration policies and the labor and investment strategies of American business. To understand fully the roots of Southern poverty, we will need a national and international perspective.

\section{REFERENCES}

Banks, E. M. (1905), The Economics of Land Tenure in Georgia. Studies in History, Economics and Public Law, Vol. 23, No. 1. New York: Columbia University Press.

Barzel, Y. (1977), "An Economic Analysis of Slavery." Journal of Law and Economics 20, 87-110.

Bell, C., and Zusman, P. (1976), “A Bargaining Theoretic Approach to Cropsharing Contracts." American Economic Review 66, 578-588.

Berthoff, R. T. (1951), "Southern Attitudes Toward Immigration, 1865-1914." Journal of Southern History 17, 328-360.

Brooks, R. P. (1914). The Agrarian Revolution in Georgia, 1865-1912. Madison, Wisc.: Bulletin of the University of Wisconsin.

Crafts, N. F. R. (1977), "Industrial Revolution in England and France: Some Thoughts on the Question, 'Why Was England First?' 'E Economic History Review 30, 429-441.

DeCanio, S. J. (1974), Agriculture in the Postbellum South. Cambridge, Mass.: MIT Press.

DuBois, W. E. B. (1901), "The Negro Landholder of Georgia." U.S. Department of Lahor Bulletin, No. 35 .

Edwards, T. J. (1913), "The Tenant System and Some Changes Since Emancipation." In A. Meier and E. Rudwick (Eds.), The Making of Black America. New York: Atheneum, 1969.

Fogel, R. W., and Engerman, S. L. (1974), Time on the Cross. Boston: Little, Brown.

Gallman, R. E., and Anderson, R. V. (1977), "Slaves as Fixed Capital." Journal of American History 64, 24-46.

Greenhut, M. L. (1970), A Theory of the Firm in Economic Space. New York: AppletonCentury-Crofts.

Greenhut, M. L., and Ohta, H. (1975), Theory of Spatial Pricing and Market Areas. Durham, N.C.: Duke University Press.

Griffin, R. W. (1964), " Reconstruction of the North Carolina Textile Industry, 1865-1885." North Carolina Historical Review 41, 34-53.

Hammond, M. B. (1897), The Cotton Industry. New York: Macmillan Co.

Helper, H. R. (1857), The Impending Crisis of the South. New York: Collier Books, 1963.

Hibbard, Benjamin (1913), "Tenancy in the Southern States." Quarterly Journal of Economics $27,482-496$.

Higgs, R. (1972), “Did Southern Farmers Discriminate?” Agricultural History 46, 325-328.

Higgs, R. (1973), "Race, Tenure and Resource Allocation in Southern Agriculture, 1910." Journal of Economic History 33, 149-169.

Higgs, R. (1977), Competition and Coercion. New York: Cambridge University Press.

Lamb, R. B. (1963), The Mule in Southern Agriculture. Berkeley: University of California Press.

Mitchell, B. (1921), The Rise of the Cotton Mills in the South. Baltimore: Johns Hopkins Press.

Ransom, R., and Sutch, R. (1975), "The 'Lock-in' Mechanism and Overproduction of Cotton in the Postbellum South." Agricultural History 49, 405-425.

Reid, J. D. (1973), "Sharecropping as an Understandable Market Response." Journal of Economic History 33, 106-130. 
Reid, J. D. (1976), "Sharecropping and Agricultural Uncertainty." Economic Development and Cultural Change 24, 549-576.

Robinson, J., and Eatwell, J. (1973). An Introduction to Modern Economics. London: McGraw-Hill.

Rosengarten, T. (1975), All God's Dangers: The Life of Nate Shaw. New York: Knopf.

Rubin. J. (1975), "The Limits of Agricultural Progress in the Nineteenth-Century South." Agricultural IIistory 49, 362-373.

Sanderson, W. C. (1974), "Does the Theory of Demand Need the Maximum Principle?" In P. A. David, and M. W. Reder (Eds.), Nations and Households in Economic Growth. New York: Academic Press.

Scitovsky, T. (1976), The Joyless Economy. New York: Oxford University Press.

Smith, R. S. (1960), Mill on the Dan. Durham, N.C.: Duke University Press.

Sonnenschein, H. (1973), "The Utility Hypothesis and Market Demand Theory." Western Economic Journal 11, 404-410.

Street, J. H. (1957), The New Revolution in the Cotton Economy. Chapel Hill: University of North Carolina Press.

Taylor, R. H. (1953), "Fertilizers and Farming in the Southeast, 1840-1950." North Carolina Historical Review 30, 307-328.

Temin, P. (1979), "Freedom and Coercion: Notes on the Analysis of Debt Peonage in One Kind of Freedom." Explorations in Economic History 16, 56-63.

Weiher, K. (1977), “The Cotton Industry and Southern Urbanization, 1880-1930." Explorations in Economic History 14, 120-140.

Woodman, H. I. (1977), "Sequel to Slavery: The New History Views the Postbellum South." Journal of Southern History 43, 523-554.

Woolfolk, G. R. (1958), The Cotton Regency. New York: Bookman Associates. 